\title{
Detection of Dual Heterodera avenae Resistance plus Tolerance Traits in Spring Wheat
}

Richard W. Smiley, Oregon State University, Columbia Basin Agricultural Research Center, Pendleton 97801; and Juliet M. Marshall, University of Idaho, Cereals Research and Extension Program, Idaho Falls 83402

\begin{abstract}
Smiley, R. W., and Marshall, J. M. 2016. Detection of dual Heterodera avenae resistance plus tolerance traits in spring wheat. Plant Dis. 100: $1677-1685$.

The cereal cyst nematode Heterodera avenae reduces wheat yield in the Pacific Northwest. Resistance and tolerance traits among spring wheat cultivars were poorly defined. Screening trials were conducted with 39 cultivars over a 2-year period in irrigated commercial fields that were infested by $H$. avenae. Comparisons were made between drill strips treated or untreated with aldicarb at the time of planting. Root sampling at the time of plant anthesis indicated that cultivars differed greatly in susceptibility to $H$. avenae, with numbers of newly produced white $H$. avenae females ranging from $<5$ to 70 per plant. Aldicarb reduced mean numbers

of white females as much as $99 \%$ on the most susceptible cultivar ('Glee') and increased mean grain yield as much as $77 \%$ for the least tolerant cultivar ('Cataldo'). Density of $H$. avenae eggs in untreated soil following harvest was significantly higher than the density in aldicarb-treated plots. Agronomically acceptable traits of resistance plus tolerance were identified in one cultivar of hard red spring wheat ('WB-Rockland') and two cultivars of hard white spring wheat ('Klasic' and 'LCS Star') but in none of the soft white spring wheat cultivars. This is the first report of spring wheat cultivars expressing the dual traits of resistance plus tolerance to $H$. avenae.
\end{abstract}

The cereal cyst nematode Heterodera avenae Woll., 1924 infests soils of localized regions of the Pacific Northwest (PNW) (Smiley 2009). This nematode reduces grain yield of wheat and barley under both rainfed and irrigated conditions (Marshall and Smiley 2016; Smiley 2009; Smiley et al. 1994, 2005, 2011a, 2012, 2013). Rotation of cereal crop hosts of $H$. avenae with 1 year of a nonhost broadleaf crop species or summer fallow are not effective in controlling losses caused by this nematode in the PNW (Marshall and Smiley 2016; Smiley et al. 1994). Extended intervals between susceptible cereal crops are seldom profitable in areas of the PNW where cereals and nonhosts such as potato or a pulse crop are produced in 2-year rotations. No chemical or biological nematicides are currently available to manage H. avenae (Smiley et al. 2012). Adequate management of cereal cyst nematodes in short rotations requires the production of cultivars that express both resistance and tolerance (Cook and Evans 1987). The objective of this research was to evaluate PNW spring wheat cultivars in an attempt to identify the dual resistance plus tolerance trait to $H$. avenae.

Resistance suppresses or prevents reproduction of the nematode, thereby reducing the density of inoculum available for invading roots of the next-planted cereal crop. Resistance is usually characterized by counting newly formed, gravid white females on roots either under controlled conditions in the greenhouse or from samples collected from cultivar screening trials in the field (Marshall and Smiley 2016; Smiley et al. 2011b, 2013). Resistance can also be estimated from numbers of eggs in soil following the harvest of cultivars grown in the field, with appropriate consideration of a "background" of residual eggs from earlier susceptible crops, which are supplemented by newly produced eggs from the most recent crop (Marshall and Smiley 2016; Smiley et al. 2013).

Tolerant cultivars are characterized as having an ability to withstand or recover from nematode invasion and to yield well in comparison with noninvaded plants. Tolerance is characterized in the field by comparing yields of individual cultivars grown in close proximity in an

Corresponding author: R. Smiley; E-mail: richard.smiley@oregonstate.edu

Accepted for publication 23 March 2016.

http://dx.doi.org/10.1094/PDIS-09-15-1055-RE

(C) 2016 The American Phytopathological Society infested soil that is either left untreated or is treated with a nematicide such as aldicarb (Marshall and Smiley 2016; Smiley et al. 2013).

Roots of both resistant and susceptible cultivars are initially invaded by second-stage juveniles of $H$. avenae, which may result in an intolerant reaction prior to the expression of resistance (O'Brien and Fisher 1977; Ogbonnaya et al. 2001; Oka et al. 1997). The intolerant reaction is characterized by a closely grouped proliferation of adventitious roots at locations where female nematodes have established a feeding syncytium, resulting in a bushy or knotted appearance to the root. Invaded roots often fail to continue growing deeply into the soil. Some resistant cultivars are unable to produce competitive grain yields when compared with susceptible cultivars that are grown without nematode pressure (Wilson et al. 1983). Growers are often reluctant to plant resistant cultivars that produce lower yields than for susceptible cultivars in noninfested soils (Rivoal and Cook 1993). Therefore, cultivars exhibiting both resistance and tolerance are required for optimal yield performance and for reducing the risk to subsequent plantings of intolerant cultivars or crops (Andersen 1961; Brown 1987; Fisher 1982; Smiley and Nicol 2009). An initial screening of $19 \mathrm{PNW}$ wheat cultivars for resistance plus tolerance identified several cultivars with resistance to $H$. avenae but none that had acceptable levels of both traits (Smiley et al. 2013). There do not appear to be any commercial North American wheat cultivars for which the registration includes a report of resistance plus tolerance to $H$. avenae (USDA-ARS-GRIN 2015).

We evaluated 39 spring wheat cultivars in three market classes (soft white, hard white, and hard red) over a 2-year period on infested commercial fields to examine our hypothesis that North American wheat cultivars with acceptable dual traits of resistance and tolerance could be identified.

\section{Materials and Methods}

Experiments during 2013 and 2014 were performed in fields infested by $H$. avenae on a farm near St. Anthony, ID. The spring wheat experiments reported here were conducted in the same fields and by using the same experimental methods described for three spring barley experiments (Marshall and Smiley 2016). Detailed experimental procedures were described by Marshall and Smiley (2016).

Briefly, the experiments were performed during 2013 in an irrigated field managed as a 2 -year rotation of potato and a spring cereal. Experiments were repeated during 2014 in a different field under the same rotational management. Two experiments were performed 
each year. One experiment included 13 cultivars of soft white spring and the other experiment included 19 hard red and 7 hard white cultivars of spring wheat. All cultivars were selected because they were being tested for other agronomic and disease traits at other locations (Marshall et al. 2015).

Experiments consisted of four replicates of each wheat entry planted into a split-plot design, with each plot consisting of two drill rows in a 0.9-by-9-m area. Cultivars were main plots (four rows) and nematicide treatments were subplots, with two adjacent rows at one side of each drill strip being treated with nematicide (nematicide subplot) and the other two rows being untreated (control subplot). Each drill strip consisted of four replicates planted end-to-end, with the cultivar being changed at 9-m intervals. The nematicide treatment consisted of aldicarb (Temik 15G; Bayer CropScience, Research Triangle Park, NC) applied into the seed row at the rate of $4.2 \mathrm{~kg}$ of aldicarb/ha.

The seed drill, seed treatment, planting rate, fertilizer application, weed control, harvest procedures, and preplant and postharvest soil sampling were described previously (Marshall and Smiley 2016). Methods of primary importance to data presented in this report are briefly described below.

Plants were dug after plant anthesis to examine roots for incidence and severity of the root knotting symptom (Fig. 1). Incidence was calculated as the percentage of plants exhibiting at least one knotted root. The severity scale (Smiley et al. 2013) was as follows: $1=$ no evidence of knotting, $2=1$ to 3 knots/root system, $3=3$ to 5 knots, $4=>5$ knots and $<20 \%$ reduction in root mass (estimated visually), and $5=>5$ knots and $>20 \%$ reduction in root mass.

Resistance was measured by counting the number of $H$. avenae swollen white females on roots. The procedure was described by Marshall and Smiley (2016). Cultivars were rated as very resistant ( $\leq 1$ swollen female/plant), resistant (1.1 to 3), moderately resistant (3.1 to 6), moderately susceptible (6.1 to 12 ), susceptible 12.1 to 25 ), or very susceptible $(>25)$.

Grain was harvested from all two-row plots. Tolerance ratings were assigned to cultivars according to the scale used previously by Smiley et al. (2013) and Marshall and Smiley (2016): very tolerant ( $\leq 5 \%$ yield increase with nematicide), tolerant (5.1 to $10 \%$ ), moderately tolerant (10.1 to $15 \%$ ), moderately intolerant (15.1 to $30 \%$ ), intolerant $(30.1$ to $50 \%)$, or very intolerant $(>50.1 \%)$.

The primary objective of this research was to identify cultivars that may have failed to meet criteria for full resistance or full tolerance but exhibited an acceptable balance among the moderate resistance and moderate tolerance traits. Data grouped over 2 years were used to establish a ranking of cultivars that exhibited at least a moderate level of resistance ( $\leq 6 \%$ swollen female/plant) plus at least a moderate level of tolerance ( $\leq 15 \%$ yield increase with nematicide).

In order to more fully interpret results of the resistance ratings based upon numbers of swollen white females developing on roots, we also determined the density of $H$. avenae eggs in soil after grain harvest. Eggs were counted after being manually released from cysts extracted from soil samples. The sampling and counting procedures were described by Marshall and Smiley (2016). Selected cultivars were sampled in both untreated and nematicide-treated plots in each experiment during 2013. During 2014, soils were sampled from three replicate plots of all cultivars in the control treatment and from three replicates of two cultivars in the nematicide treatment: 'Alpowa' and 'UI Stone' soft white wheat and 'Glee' and 'Jefferson' hard red wheat.

Statistical analyses. For clarity, data for the hard red plus hard white wheat experiment was divided into two groups to report results specific to each of the three market classes of spring wheat: soft white, hard red, and hard white. Grain yield and disease data averaged over 2 years were analyzed using three-way analysis of variance (ANOVA) for individual wheat classes, with year as the main plot, cultivar as the subplot, nematicide treatment as the subsubplot, and replicates as blocks. Analyses were performed on nematode density data normalized by using the $\ln (x+1)$ transformation. Logarithmic means were back transformed into real numbers for presentation in the tables. Means of ordinate data for root knotting severity were analyzed by the Kruskal-Wallis test. When the Pearson's $\chi^{2}$ value for the experiment was significant at $\alpha<0.05$, the treatments were examined pairwise to determine which treatments differed significantly. For the soft white and hard red wheat classes, selected cultivars were sampled from both control and nematicide-treated plots each year and those cultivars were analyzed separately to examine effects of year, cultivar, and nematicide treatments. Data for those cultivars were analyzed using year as the main plot factor, cultivar as the subplot factor, and nematicide as the subsubplot factor. ANOVA was performed using CoStat Statistical Software (Co-Stat v. 6.400; CoHort Software, Monterey, CA). When treatment means were significant at $\alpha<0.05$, means were separated using the Tukey's honestly significant difference (HSD) test. Because the main effect of year was highly significant in most analyses, the data for each of the three trials were also analyzed for individual years using two-way ANOVA with year as main plot, cultivar as the subplot, and replicates as blocks. Data for each wheat market class are reported as the means and standard error of the means for trials performed during each year. Regression analysis was used to determine whether the number of white females produced on cultivars within the control treatment (no nematicide application) of the soft white and hard red plus hard white wheat market classes was associated with the number of eggs per kilogram of soil detected in soil following harvest. Linear and quadratic associations were modeled using both raw and transformed data for all plots within market groups, and also by using means of replicates of cultivars within market groups.

\section{Results}

Preplant nematode density. The initial density of $H$. avenae in the trial area during 2013 was 22,176 eggs plus juveniles $/ \mathrm{kg}$ of soil. During 2014, the initial density was 3,309 eggs plus juveniles/kg for the combined block of hard red and hard white wheat cultivars, and 11,880 eggs plus juveniles/kg for the block of soft white wheat cultivars.

Plant growth and development. Seed was planted into soils that had seed-zone temperatures of $8.9^{\circ} \mathrm{C}$ in 2013 (4.0-cm depth) and $6.7^{\circ} \mathrm{C}$ in 2014 (2.4-cm depth). Seedlings emerged more than 3 weeks after planting, on approximately 10 May 2013 and 5 May 2014.

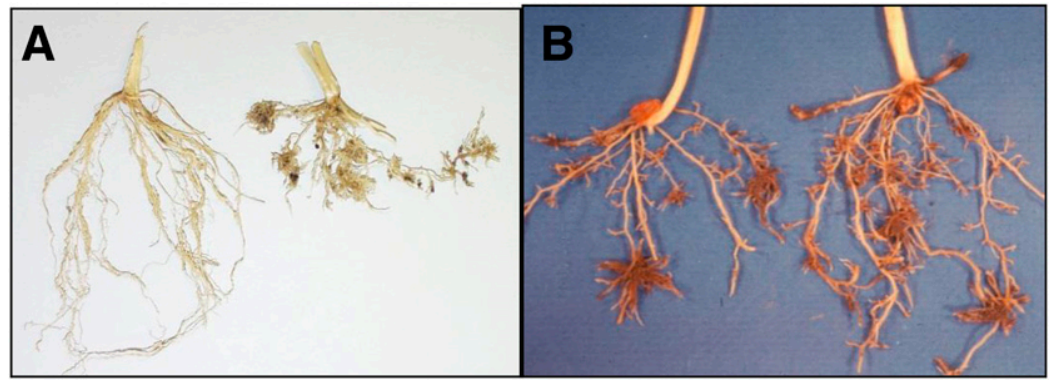

Fig. 1. Spring wheat with shallow, knotted roots caused by Heterodera avenae. A, Plant with very low intensity of nematode invasion (left) compared with a heavily invaded plant (right) and $\mathbf{B}$, close-up view of the classic proliferation of adventitious roots near feeding sites where cysts will develop. 
Anthesis was initiated on or about 1 July 2013 and 12 July 2014. Growth of some cultivars was visually taller and denser in aldicarbtreated plots than in nontreated plots but no measurements were made.

Disease incidence and severity. Root knotting was present on 98 to $100 \%$ of the plants in each trial during each year. This occurred in the nematicide-treated plots as well as in the nontreated control (data not shown). Severity of the root-knotting symptom in the control treatment of each wheat class differed significantly $(P<0.0001)$ for the main effect of year. Mean severity ratings were 4.3 (range of 3.7 to 4.5 ) and 5.0 (range of 4.8 to 5.0) during 2013 and 2014, respectively, for 19 hard red cultivars and the 7 hard white cultivars $\left(\mathrm{HSD}_{0.05}=0.1\right.$; data not shown); and 4.3 (range of 4.0 to 4.5 ) and 4.9 (range of 4.3 to 5.0) during 2013 and 2014, respectively, for 13 soft white cultivars. Severity ratings did not differ among cultivars for each of the three wheat classes $(P>0.05)$ during either year, and the year-cultivar interaction was also not significant for any of the three wheat classes.

For the two cultivars in which roots were also evaluated in the nematicide treatment for the soft white and hard red wheat classes, the effects of year and nematicide treatment were each significant

Table 1. Evaluation of 19 hard red spring wheat cultivars for resistance (Res) and tolerance (Tol) to Heterodera avenae in two fields near St. Anthony, ID during 2013 and $2014^{\mathrm{u}}$

\begin{tabular}{|c|c|c|c|c|c|c|}
\hline \multirow[b]{2}{*}{ Cultivar } & \multirow[b]{2}{*}{ Females/plant ${ }^{v}$} & \multirow[b]{2}{*}{$\operatorname{Res}^{w}$} & \multicolumn{3}{|c|}{ Grain yield (kg/ha) } & \multirow[b]{2}{*}{ Tol $^{\mathbf{Z}}$} \\
\hline & & & Control & Treated $^{\mathrm{x}}$ & Increase $(\%)^{y}$ & \\
\hline \multicolumn{7}{|l|}{2013} \\
\hline WB-Rockland & $2.3 \pm 0.5 \mathrm{~g}$ & $\mathrm{R}$ & $3,118 \pm 570 a$ & $3,545 \pm 328 a b$ & $20.2 \pm 12.7 \mathrm{a}$ & MI \\
\hline WB9576 & $10.9 \pm 5.5 \mathrm{e}-\mathrm{g}$ & MS & $2,929 \pm 321 \mathrm{a}$ & $3,197 \pm 325 \mathrm{ab}$ & $10.2 \pm 6.7 \mathrm{a}$ & MT \\
\hline UI Platinum & $11.0 \pm 7.8 \mathrm{e}-\mathrm{g}$ & MS & $2,610 \pm 375 a$ & $3,366 \pm 500 \mathrm{ab}$ & $28.6 \pm 3.0 \mathrm{a}$ & MI \\
\hline WB9229 & $11.6 \pm 5.8 \mathrm{e}-\mathrm{g}$ & MS & $2,337 \pm 482 \mathrm{a}$ & $3,197 \pm 390 a b$ & $41.3 \pm 16.2 \mathrm{a}$ & I \\
\hline Kelse & $18.4 \pm 17.4 \mathrm{c}-\mathrm{g}$ & $\mathrm{S}$ & $3,279 \pm 662 \mathrm{a}$ & $3,709 \pm 577 \mathrm{ab}$ & $19.7 \pm 15.9 \mathrm{a}$ & MI \\
\hline Jefferson & $21.7 \pm 10.6 \mathrm{~b}-\mathrm{g}$ & $\mathrm{S}$ & $2,735 \pm 78 \mathrm{a}$ & $4,442 \pm 460 \mathrm{a}$ & $61.7 \pm 13.3 \mathrm{a}$ & VI \\
\hline Choteau & $22.3 \pm 8.2 \mathrm{~b}-\mathrm{g}$ & $\mathrm{S}$ & $2,498 \pm 310 a$ & $3,143 \pm 243 \mathrm{ab}$ & $29.9 \pm 12.1 \mathrm{a}$ & MI \\
\hline IDO862T & $22.9 \pm 12.4 \mathrm{~b}-\mathrm{g}$ & $\mathrm{S}$ & $2,377 \pm 315 a$ & $2,709 \pm 266 \mathrm{ab}$ & $18.7 \pm 18.3 \mathrm{a}$ & MI \\
\hline IDO1202S & $23.9 \pm 2.0 \mathrm{~b}-\mathrm{g}$ & $\mathrm{S}$ & $2,891 \pm 558 \mathrm{a}$ & $3,869 \pm 438 a b$ & $42.6 \pm 15.8 \mathrm{a}$ & I \\
\hline Cabernet & $27.4 \pm 1.8 \mathrm{~b}-\mathrm{f}$ & VS & $2,082 \pm 224 \mathrm{a}$ & $2,836 \pm 324 \mathrm{ab}$ & $39.1 \pm 15.1 \mathrm{a}$ & I \\
\hline LCS Iron & $30.9 \pm 7.5 \mathrm{~b}-\mathrm{f}$ & VS & $3,035 \pm 415 a$ & $4,061 \pm 247 \mathrm{ab}$ & $38.5 \pm 12.3 \mathrm{a}$ & I \\
\hline UI Winchester & $36.3 \pm 15.3 \mathrm{~b}-\mathrm{e}$ & VS & $2,450 \pm 204 \mathrm{a}$ & $2,860 \pm 150 \mathrm{ab}$ & $18.6 \pm 9.3 \mathrm{a}$ & MI \\
\hline Glee & $38.9 \pm 9.9 \mathrm{~b}-\mathrm{d}$ & VS & $3,230 \pm 609 a$ & $3,907 \pm 356 \mathrm{ab}$ & $27.3 \pm 12.8 \mathrm{a}$ & MI \\
\hline Alzada & $40.7 \pm 7.9 \mathrm{~b}-\mathrm{d}$ & VS & $2,616 \pm 622 a$ & $2,743 \pm 579 a b$ & $10.3 \pm 9.4 \mathrm{a}$ & MT \\
\hline Bullseye & $44.4 \pm 5.8 \mathrm{a}-\mathrm{c}$ & VS & $2,433 \pm 144 a$ & $2,984 \pm 156 \mathrm{ab}$ & $25.0 \pm 13.3 \mathrm{a}$ & MI \\
\hline IDO862E & $45.5 \pm 22.3 \mathrm{a}-\mathrm{c}$ & VS & $2,012 \pm 344 \mathrm{a}$ & $2,517 \pm 381 b$ & $31.9 \pm 19.8 \mathrm{a}$ & I \\
\hline SY Basalt & $46.7 \pm 23.9 \mathrm{ab}$ & VS & $2,950 \pm 457 \mathrm{a}$ & $4,100 \pm 634 a b$ & $39.4 \pm 10.6 \mathrm{a}$ & I \\
\hline Westbred 936 & $70.1 \pm 29.8 \mathrm{a}$ & VS & $1,855 \pm 51 \mathrm{a}$ & $3,028 \pm 298 \mathrm{ab}$ & $62.7 \pm 14.4 \mathrm{a}$ & VI \\
\hline Mean & 26.7 & VS & 2,610 & 3,323 & 26.3 & MI \\
\hline$P>F$ & 0.0254 & $\ldots$ & 0.3920 & 0.0112 & 0.2191 & $\ldots$ \\
\hline $\mathrm{HSD}_{0.05}$ & $\ldots$ & $\ldots$ & Ns & 1,040 & $\mathrm{~ns}$ & $\ldots$ \\
\hline \multicolumn{7}{|l|}{2014} \\
\hline WB-Rockland & $0.7 \pm 0.1 \mathrm{c}$ & VR & $4,910 \pm 169 \mathrm{a}$ & $5,104 \pm 116 \mathrm{~cd}$ & $8.7 \pm 5.7 \mathrm{a}$ & $\mathrm{T}$ \\
\hline LCS Iron & $1.3 \pm 0.6 \mathrm{c}$ & $\mathrm{R}$ & $5,133 \pm 221 a$ & $5,824 \pm 137 \mathrm{a}-\mathrm{c}$ & $13.8 \pm 2.4 \mathrm{a}$ & MT \\
\hline Choteau & $1.4 \pm 0.6 \mathrm{c}$ & $\mathrm{R}$ & $4,847 \pm 270 a$ & $4,982 \pm 257 \mathrm{~d}$ & $6.7 \pm 7.9 \mathrm{a}$ & $\mathrm{T}$ \\
\hline Alzada & $2.1 \pm 1.2 \mathrm{c}$ & $\mathrm{R}$ & $4,817 \pm 236 a$ & $5,135 \pm 156 \mathrm{~cd}$ & $14.6 \pm 5.3 \mathrm{a}$ & MT \\
\hline UI Winchester & $2.2 \pm 0.5 \mathrm{c}$ & $\mathrm{R}$ & $4,574 \pm 334 \mathrm{a}$ & $4,993 \pm 334 \mathrm{~d}$ & $20.9 \pm 11.6 \mathrm{a}$ & MI \\
\hline IDO862E & $2.3 \pm 1.1 \mathrm{c}$ & $\mathrm{R}$ & $4,880 \pm 358 a$ & $5,292 \pm 420 \mathrm{~b}-\mathrm{d}$ & $18.0 \pm 8.4 \mathrm{a}$ & MI \\
\hline SY Basalt & $2.8 \pm 2.1 \mathrm{c}$ & $\mathrm{R}$ & $5,379 \pm 427 a$ & $5,512 \pm 235 \mathrm{~b}-\mathrm{d}$ & $8.1 \pm 10.3 \mathrm{a}$ & $\mathrm{T}$ \\
\hline Cabernet & $2.9 \pm 1.0 \mathrm{c}$ & $\mathrm{R}$ & $5,024 \pm 370 a$ & $5,093 \pm 255 \mathrm{~cd}$ & $4.4 \pm 6.6 \mathrm{a}$ & VT \\
\hline Jefferson & $5.3 \pm 2.2 \mathrm{bc}$ & MR & $5,103 \pm 378 a$ & $5,465 \pm 344 \mathrm{~b}-\mathrm{d}$ & $15.7 \pm 3.4 \mathrm{a}$ & MI \\
\hline Bullseye & $4.1 \pm 1.8 \mathrm{bc}$ & MR & $5,285 \pm 172 a$ & $5,494 \pm 191 \mathrm{~b}-\mathrm{d}$ & $8.3 \pm 4.8 \mathrm{a}$ & $\mathrm{T}$ \\
\hline WB9576 & $4.7 \pm 1.3 \mathrm{bc}$ & MR & $5,458 \pm 347 \mathrm{a}$ & $5,449 \pm 216 b-d$ & $1.3 \pm 8.0 \mathrm{a}$ & VT \\
\hline UI Platinum & $6.7 \pm 3.1 \mathrm{bc}$ & MS & $5,309 \pm 333 a$ & $5,629 \pm 240 \mathrm{a}-\mathrm{c}$ & $12.9 \pm 4.5 \mathrm{a}$ & MT \\
\hline IDO862T & $7.5 \pm 4.0 \mathrm{bc}$ & MS & $5,253 \pm 347 a$ & $5,563 \pm 276 \mathrm{a}-\mathrm{d}$ & $13.4 \pm 4.8 \mathrm{a}$ & MT \\
\hline Kelse & $7.6 \pm 3.9 \mathrm{bc}$ & MS & $5,343 \pm 334 \mathrm{a}$ & $5,730 \pm 227 \mathrm{a}-\mathrm{c}$ & $16.8 \pm 8.0 \mathrm{a}$ & MI \\
\hline Glee & $8.9 \pm 2.5 \mathrm{bc}$ & MS & $5,202 \pm 305 a$ & $5,359 \pm 301 \mathrm{~b}-\mathrm{d}$ & $6.5 \pm 2.6 \mathrm{a}$ & $\mathrm{T}$ \\
\hline WB9229 & $9.3 \pm 8.2 \mathrm{bc}$ & MS & $5,524 \pm 328 \mathrm{a}$ & $5,836 \pm 331 \mathrm{ab}$ & $11.9 \pm 0.7 \mathrm{a}$ & MT \\
\hline IDO1202S & $12.7 \pm 6.5 \mathrm{~b}$ & $\mathrm{~S}$ & $5,886 \pm 336 a$ & $6,232 \pm 240 a$ & $12.6 \pm 4.7 \mathrm{a}$ & MT \\
\hline Volt & $50.3 \pm 22.9 \mathrm{a}$ & VS & $5,137 \pm 337 a$ & $5,671 \pm 181 \mathrm{a}$ & $23.4 \pm 2.8 \mathrm{a}$ & MI \\
\hline Westbred 936 & $51.4 \pm 34.7 \mathrm{a}$ & VS & $4,717 \pm 270 a$ & $5,153 \pm 124 \mathrm{~cd}$ & $21.0 \pm 7.3 \mathrm{a}$ & MI \\
\hline Mean & 9.7 & MS & 4,880 & 5,448 & 12.5 & MT \\
\hline$P>F$ & 0.0279 & $\ldots$ & 0.0604 & 0.0353 & 0.3014 & $\ldots$ \\
\hline $\mathrm{HSD}_{0.05}$ & $\ldots$ & $\ldots$ & ns & 680 & Ns & $\ldots$ \\
\hline
\end{tabular}

u Means followed by the same letter within a column did not differ significantly at $\alpha=0.05$ as determined by Tukey's honestly significant difference (HSD) test; ns $=$ not significant.

$\checkmark$ Number of $H$. avenae white females produced per plant for the control (no-nematicide) treatment only; sampling was performed at approximately the time of anthesis.

w Phenotypic resistance reaction: very resistant (VR; $\leq 1$ swollen female/plant), resistant (R; 1.1 to 3 ), moderately resistant (MR; 3.1 to 6), moderately susceptible (MS; 6.1 to 12 ), susceptible (S; 12.1 to 25$)$, or very susceptible (VS; $>25$ ).

${ }^{x}$ Nematicide treatment included application of aldicarb (at $4.2 \mathrm{~kg} / \mathrm{ha}$ ) in the seed row at the time of planting.

y Percentage increase in grain yield due to application of nematicide.

z Phenotypic tolerance reaction: very tolerant (VT; $<5 \%$ yield response to nematicide), tolerant (T; 5 to $10 \%$ ), moderately tolerant (MT; 10 to $15 \%$ ), moderately intolerant (MI; 15 to $30 \%$ ), intolerant (I; 30 to $50 \%$ ), or very intolerant (VI; $>50 \%$ ). 
$(P<0.0001)$ and the effect of cultivar was not significant $(P>0.25)$. The mean severity of the root-knotting symptom in each experiment was greater during 2014 (4.9) than during 2013 (3.7; data not shown), and was greater in the control plots than in the nematicide treated plots: 4.6 and $3.9\left(\mathrm{HSD}_{0.05}=0.2\right)$, respectively, for the hard red cultivars and 4.6 and $4.0\left(\mathrm{HSD}_{0.05}=0.4\right)$, respectively, for the soft white cultivars.

Disease resistance. Numbers of newly produced $H$. avenae swollen white females were significantly influenced $(P<0.05)$ by the main effect of year and cultivar for each market class. The year-cultivar interaction was not significant $(P<0.05)$ for any of the three wheat classes. Numbers of white females were greater during 2013 than during 2014 (Tables 1 to 3). For the two cultivars in which white females were quantified in the nematicide treatment for the hard red and soft white wheat classes, the main treatment effect for nematicide was significant $(P<0.0001)$ for both classes. For Glee, the most susceptible cultivar examined in these comparisons of treated and untreated plots, the application of nematicide reduced the number of white females by $99 \%$, from 38.9 to 0.5 per plant. The effect of year was not significant $(P>0.05)$. The main treatment effect for cultivar was not significant $(P>0.30)$ for any wheat class; however, the year-cultivar interaction was significant $(P=0.02)$ for the soft white wheat. In each case, the numbers of white females were much higher on roots in the control plots than in the nematicide-treated plots. The mean numbers of white females in the control and nematicide treatments were 18.8 and $1.4\left(\mathrm{HSD}_{0.05}=7.6\right)$, respectively, for the hard red wheats and 18.3 and $3.7\left(\mathrm{HSD}_{0.05}=5.2\right)$, respectively, for the soft white wheats.

Numbers of swollen white females extracted and counted during 2014 were too low to provide reliable distinctions among cultivars. 'WB-Rockland' was the only hard red cultivar rated as resistant during both years (Table 1), and WB-Rockland plus 10 additional cultivars were rated as resistant during 2014. 'LCS Star' was the only hard white cultivar rated as resistant during both years (Table 2), and it plus three additional cultivars were rated as resistant during 2014. No cultivars of soft white were rated as moderately resistant, resistant, or very resistant to $H$. avenae during 2013 (Table 1). During 2014, 9 of the 13 soft white cultivars rated at moderately resistant, resistant, or very resistant.

Disease tolerance. Grain yields averaged across entries were significantly greater during 2014 than during 2013 for all three wheat classes. Treatment effects for cultivar $(P<0.05)$ and nematicide $(P<0.0001)$ also each differed significantly for each wheat class. Mean grain yields were higher in nematicide-treated plots compared with the controls; 5,164 versus $2,967 \mathrm{~kg} / \mathrm{ha}\left(\mathrm{HSD}_{0.05}=711\right)$ for hard red cultivars, 5,517 versus $3,351 \mathrm{~kg} / \mathrm{ha}\left(\mathrm{HSD}_{0.05}=5197\right)$ for hard white cultivars, and 5,653 versus $4,903 \mathrm{~kg} / \mathrm{ha}\left(\mathrm{HSD}_{0.05}=115\right)$ for soft white cultivars. None of the treatment interactions were statistically significant at $P=0.05$ for the three wheat classes. Grain yields for each cultivar and year are presented in Tables 1 to 3 . Grain yields differed significantly $(P<0.0001)$ between nematicide treatments for all three classes, with yields being increased by 17,14 , and $15 \%$ for hard red, hard white, and soft white cultivars, respectively.

The percentage increase in grain yield due to application of nematicide differed significantly among cultivars only for the soft white cultivars during 2013 (Tables 1 to 3 ).

Dual resistance and tolerance to $H$. avenae. Cultivars with acceptable dual traits of resistance plus tolerance were identified by grouping data over 2 years (Table 4). Hard red WB-Rockland and hard white 'Klasic' met these dual-trait criteria, and yields of both cultivars were statistically equivalent to the highest yielding cultivar in that experiment. Hard white LCS Star was ranked as resistant but did not quite meet the dual criteria only because it had a mean tolerance rating of 15.5, which did not meet the strict predetermined minimum limit of 15.0 to achieve the moderately tolerant rating. Nevertheless, LCS Star

Table 2. Evaluation of seven hard white spring wheat cultivars for resistance (Res) and tolerance (Tol) to Heterodera avenae in two fields near St. Anthony, ID during 2013 and $2014^{\mathrm{u}}$

\begin{tabular}{|c|c|c|c|c|c|c|}
\hline \multirow[b]{2}{*}{ Cultivar } & \multirow[b]{2}{*}{ Females/plant ${ }^{v}$} & \multirow[b]{2}{*}{$\operatorname{Res}^{w}$} & \multicolumn{3}{|c|}{ Grain yield (kg/ha) } & \multirow[b]{2}{*}{ Tol $^{\mathrm{z}}$} \\
\hline & & & Control & Treated $^{\mathrm{x}}$ & Increase $(\%)^{y}$ & \\
\hline \multicolumn{7}{|l|}{2013} \\
\hline LCS Star & $4.2 \pm 3.1 \mathrm{a}$ & MR & $3,723 \pm 547 a$ & $4,200 \pm 679 a$ & $12.4 \pm 5.5 \mathrm{~b}$ & MT \\
\hline Klasic & $6.9 \pm 2.6 \mathrm{a}$ & MS & $2,866 \pm 418 \mathrm{a}$ & $3,369 \pm 286 a$ & $23.1 \pm 15.0 \mathrm{a}$ & MI \\
\hline Dayn & $14.6 \pm 14.0 \mathrm{a}$ & $\mathrm{S}$ & $4,011 \pm 680 a$ & $4,727 \pm 429 a$ & $25.0 \pm 15.0 \mathrm{a}$ & MI \\
\hline WB-Idamax & $26.1 \pm 12.8 \mathrm{a}$ & VS & $2,581 \pm 309 a$ & $3,584 \pm 250 \mathrm{a}$ & $34.3 \pm 10.0 \mathrm{a}$ & I \\
\hline Snow Crest & $35.9 \pm 16.4 \mathrm{a}$ & VS & $2,709 \pm 417 \mathrm{a}$ & $3,483 \pm 278 \mathrm{a}$ & $29.2 \pm 4.3 \mathrm{a}$ & MI \\
\hline Blanca Grande & $36.7 \pm 6.0 \mathrm{a}$ & VS & $2,988 \pm 489 a$ & $3,360 \pm 395 a$ & $15.1 \pm 5.8 \mathrm{a}$ & MI \\
\hline WB-Paloma & $42.7 \pm 16.8 \mathrm{a}$ & VS & $2,316 \pm 243 a$ & $3,197 \pm 223 \mathrm{a}$ & $41.0 \pm 11.9 \mathrm{a}$ & I \\
\hline Mean & 23.9 & $\mathrm{~S}$ & 3,028 & 3,674 & 25.7 & MI \\
\hline$P>F$ & 0.1295 & $\ldots$ & 0.1991 & 0.1694 & 0.5510 & $\ldots$ \\
\hline $\mathrm{HSD}_{0.05}$ & $\ldots$ & $\ldots$ & $\mathrm{ns}$ & $\mathrm{ns}$ & $\mathrm{ns}$ & $\ldots$ \\
\hline \multicolumn{7}{|l|}{2014} \\
\hline Dayn & $0.5 \pm 0.3 b$ & VR & $6,299 \pm 280 a$ & $6,397 \pm 206 a$ & $3.7 \pm 4.9 \mathrm{a}$ & VT \\
\hline LCS Star & $0.9 \pm 0.3 b$ & VR & $4,837 \pm 447 b$ & $5,610 \pm 185 a$ & $18.6 \pm 10.0 \mathrm{a}$ & MI \\
\hline Klasic & $2.0 \pm 0.4 \mathrm{~b}$ & $\mathrm{R}$ & $5,366 \pm 303 b$ & $5,516 \pm 241 \mathrm{ab}$ & $6.8 \pm 6.6 \mathrm{a}$ & $\mathrm{T}$ \\
\hline Blanca Grande & $4.9 \pm 3.7 \mathrm{ab}$ & MR & $5,273 \pm 237 b$ & $5,419 \pm 277 a b$ & $5.7 \pm 3.6 \mathrm{a}$ & $\mathrm{T}$ \\
\hline WB-Idamax & $6.3 \pm 3.1 \mathrm{ab}$ & MS & $5,435 \pm 209 b$ & $5,692 \pm 160 a b$ & $10.5 \pm 7.1 \mathrm{a}$ & MT \\
\hline WB-Paloma & $9.7 \pm 3.8 \mathrm{a}$ & MS & $5,539 \pm 218 b$ & $5,801 \pm 115 a b$ & $10.6 \pm 6.2 \mathrm{a}$ & MT \\
\hline Snow Crest & $16.0 \pm 6.7 \mathrm{a}$ & $\mathrm{S}$ & $5,486 \pm 350 b$ & $5,938 \pm 267 \mathrm{ab}$ & $18.2 \pm 1.4 \mathrm{a}$ & MI \\
\hline Mean & 5.8 & MR & 5,267 & 5,768 & 10.6 & MT \\
\hline$P>F$ & 0.0326 & $\ldots$ & 0.0491 & 0.0815 & 0.3521 & $\ldots$ \\
\hline $\mathrm{HSD}_{0.05}$ & $\ldots$ & $\ldots$ & 749 & ns & $\mathrm{ns}$ & $\ldots$ \\
\hline
\end{tabular}

u Means followed by the same letter within a column did not differ significantly at $\alpha=0.05$ as determined by Tukey's honestly significant difference (HSD) test; ns $=$ not significant.

v Number of $H$. avenae white females produced per plant for the control (no-nematicide) treatment only; sampling was performed at approximately the time of anthesis.

w Phenotypic resistance reaction: very resistant (VR; $\leq 1$ swollen female/plant), resistant (R; 1.1 to 3 ), moderately resistant (MR; 3.1 to 6), moderately susceptible (MS; 6.1 to 12 ), susceptible (S; 12.1 to 25$)$, or very susceptible (VS; $>25$ ).

${ }^{x}$ Nematicide treatment included application of aldicarb (at $4.2 \mathrm{~kg} / \mathrm{ha}$ ) in the seed row at the time of planting.

y Percentage increase in grain yield due to application of nematicide.

z Phenotypic tolerance reaction: very tolerant (VT; $<5 \%$ yield response to nematicide), tolerant (T; 5 to $10 \%$ ), moderately tolerant (MT; 10 to $15 \%$ ), moderately intolerant (MI; 15 to $30 \%$ ), intolerant (I; 30 to $50 \%$ ), or very intolerant (VI; $>50 \%$ ). 
was considered to have agronomically acceptable levels of both resistance and tolerance. Hard red 'WB9576' and soft white 'Alpowa' were ranked as tolerant but were moderately susceptible. Soft white 'Cataldo' was ranked as moderately resistant but was intolerant. No soft white cultivar met the dual criteria.

Postharvest density of eggs. Residual numbers of eggs from cysts were determined for selected cultivars in both aldicarb-treated and control plots during 2013. Cultivars examined in the hard wheat experiment during 2013 included Glee, Jefferson, LCS Star, Klasic, 'SY Basalt', WB-Rockland, and 'Westbred 936'. The nematicide application reduced $(P<0.0001)$ the mean postharvest number of eggs by $59 \%$, from 38,039 to 15,023 eggs $/ \mathrm{kg}$ (data not shown). The range of percent reduction in egg density due to nematicide application was from 24 to $82 \%$ for the least (WB-Rockland) and most (SY Basalt) susceptible cultivars, respectively. The main effect for cultivar was significant, with WB Rockland leaving fewer eggs in soil than Glee, Jefferson, SY Basalt, and Westbred 936 (Table 5). Cultivars evaluated in the soft white wheat experiment included Alpowa, Cataldo, 'IDO 851', UI Stone, and 'WB6430'. The nematicide treatment significantly $(P<$ 0.0001 ) reduced the mean postharvest egg density by $82 \%$, from
76,138 to 13,798 eggs $/ \mathrm{kg}$ of soil, in the control and nematicide treatments, respectively (data not shown). The range of percent reduction in egg density due to nematicide application was from 71 to $92 \%$ for the least (Cataldo) and most (IDO 851) susceptible cultivars, respectively. The main effect for cultivar was also significant, with the number of eggs in control plots being less following Alpowa and Cataldo than following IDO 851 (Table 5).

Because the nematicide clearly reduced the density of $H$. avenae eggs in soil, with many or most of the remaining eggs in nematicide treatments representing eggs from cysts developed during earlier years, it was determined that sampling emphasis during 2014 should be focused on differences among cultivars in the control treatment. All cultivars in the control plots and two cultivars in the nematicidetreated plots were sampled during 2014. The cultivars sampled in the nematicide treatment were the same as those for which the root disease symptoms and numbers of swollen white females had been examined during 2013. For the two cultivars sampled in control and nematicide treatments during both years, the main effects of year and nematicide were significant $(P<0.05)$ for both experiments. The main effect for cultivar was significant $(P=0.05)$ for the soft

Table 3. Evaluation of 13 soft white spring wheat cultivars for resistance (Res) and tolerance (Tol) to Heterodera avenae in two fields near St. Anthony, ID during 2013 and $2014^{\mathrm{u}}$

\begin{tabular}{|c|c|c|c|c|c|c|}
\hline \multirow[b]{2}{*}{ Cultivar } & \multirow[b]{2}{*}{ Females/plant ${ }^{\mathbf{v}}$} & \multirow[b]{2}{*}{ Res $^{w}$} & \multicolumn{3}{|c|}{ Grain yield (kg/ha) } & \multirow[b]{2}{*}{ Tol $^{\mathbf{z}}$} \\
\hline & & & Control & Treated $^{\mathrm{x}}$ & Increase $(\%)^{\mathbf{y}}$ & \\
\hline \multicolumn{7}{|l|}{2013} \\
\hline Cataldo & $7.3 \pm 3.5 \mathrm{a}$ & MS & $3,322 \pm 686 a$ & $5,729 \pm 1,073 \mathrm{a}$ & $77.1 \pm 17.4 \mathrm{a}$ & VI \\
\hline IDO 852 & $18.8 \pm 7.6 \mathrm{a}$ & $\mathrm{S}$ & $4,124 \pm 364 a$ & $5,240 \pm 538 \mathrm{a}$ & $26.7 \pm 3.5 b c$ & MI \\
\hline UI Stone & $23.2 \pm 14.9 \mathrm{a}$ & S & $4,221 \pm 333 a$ & $5,128 \pm 364 \mathrm{a}$ & $22.8 \pm 8.7 \mathrm{bc}$ & MI \\
\hline Alpowa & $24.9 \pm 1.2 \mathrm{a}$ & $\mathrm{S}$ & $4,418 \pm 255 \mathrm{a}$ & $4,631 \pm 224 a$ & $5.2 \pm 8.2 \mathrm{c}$ & $\mathrm{T}$ \\
\hline Babe & $28.6 \pm 5.7 \mathrm{a}$ & VS & $4,134 \pm 408 \mathrm{a}$ & $5,211 \pm 454 \mathrm{a}$ & $27.0 \pm 5.6 \mathrm{bc}$ & MI \\
\hline UI Petit & $34.7 \pm 12.4 \mathrm{a}$ & VS & $4,125 \pm 488 \mathrm{a}$ & $5,107 \pm 459 \mathrm{a}$ & $26.0 \pm 10.9 \mathrm{bc}$ & MI \\
\hline WB6121 & $36.3 \pm 10.0 \mathrm{a}$ & VS & $4,110 \pm 580 \mathrm{a}$ & $4,642 \pm 488 \mathrm{a}$ & $14.6 \pm 5.0 \mathrm{bc}$ & MT \\
\hline Penawawa & $40.0 \pm 6.9 \mathrm{a}$ & $\mathrm{VS}$ & $3,900 \pm 473 a$ & $4,672 \pm 374 \mathrm{a}$ & $22.3 \pm 13.3 \mathrm{bc}$ & MI \\
\hline IDO 854 & $43.5 \pm 16.2 \mathrm{a}$ & VS & $3,619 \pm 740 a$ & $4,833 \pm 264 \mathrm{a}$ & $42.3 \pm 22.6 \mathrm{~b}$ & I \\
\hline Alturas & $43.6 \pm 26.4 \mathrm{a}$ & VS & $4,280 \pm 612 \mathrm{a}$ & $5,083 \pm 326 \mathrm{a}$ & $23.8 \pm 12.9 \mathrm{bc}$ & MI \\
\hline Seahawk & $44.4 \pm 7.2 \mathrm{a}$ & VS & $4,289 \pm 524 a$ & $5,165 \pm 319 a$ & $24.4 \pm 12.0 \mathrm{bc}$ & MI \\
\hline WB6430 & $45.8 \pm 18.3 \mathrm{a}$ & VS & $5,004 \pm 526 \mathrm{a}$ & $5,793 \pm 103 a$ & $19.1 \pm 11.4 \mathrm{bc}$ & MI \\
\hline IDO 851 & $52.6 \pm 23.9 \mathrm{a}$ & VS & $4,174 \pm 483 \mathrm{a}$ & $5,066 \pm 509 \mathrm{a}$ & $21.9 \pm 3.3 b c$ & MI \\
\hline Mean & 34.1 & VS & 4,132 & 5,099 & 23.4 & MI \\
\hline$P>F$ & 0.5227 & $\ldots$ & 0.5806 & 0.6992 & 0.0251 & $\ldots$ \\
\hline $\mathrm{HSD}_{0.05}$ & ns & $\ldots$ & ns & ns & 30.5 & $\ldots$ \\
\hline \multicolumn{7}{|l|}{2014} \\
\hline IDO 851 & $0.5 \pm 0.1 \mathrm{a}$ & VR & $5,581 \pm 297 \mathrm{a}$ & $6,363 \pm 404 a$ & $14.1 \pm 4.2 \mathrm{a}$ & MT \\
\hline IDO 854 & $2.4 \pm 0.7 \mathrm{a}$ & $\mathrm{R}$ & $5,905 \pm 465 \mathrm{a}$ & $6,382 \pm 379 a$ & $8.6 \pm 3.1 \mathrm{a}$ & $\mathrm{T}$ \\
\hline IDO 852 & $2.5 \pm 1.0 \mathrm{a}$ & $\mathrm{R}$ & $5,958 \pm 468 \mathrm{a}$ & $6,475 \pm 492 \mathrm{a}$ & $8.9 \pm 3.1 \mathrm{a}$ & $\mathrm{T}$ \\
\hline Babe & $2.7 \pm 0.6 \mathrm{a}$ & $\mathrm{R}$ & $5,235 \pm 267 a$ & $5,923 \pm 203 a$ & $13.8 \pm 5.4 \mathrm{a}$ & MT \\
\hline Cataldo & $3.1 \pm 2.3 \mathrm{a}$ & MR & $6,133 \pm 150 a$ & $6,214 \pm 346 a$ & $1.1 \pm 3.5 \mathrm{a}$ & VT \\
\hline Penawawa & $3.3 \pm 1.2 \mathrm{a}$ & MR & $5,610 \pm 580 a$ & $6,205 \pm 453 a$ & $11.6 \pm 4.0 \mathrm{a}$ & MT \\
\hline UI Petit & $4.7 \pm 2.5 \mathrm{a}$ & MR & $6,063 \pm 491 \mathrm{a}$ & $6,505 \pm 247 a$ & $9.3 \pm 4.7 \mathrm{a}$ & $\mathrm{T}$ \\
\hline WB6121 & $4.7 \pm 3.5 \mathrm{a}$ & MR & $5,596 \pm 210 \mathrm{a}$ & $6,083 \pm 340 a$ & $8.5 \pm 2.5 \mathrm{a}$ & $\mathrm{T}$ \\
\hline Alpowa & $5.1 \pm 2.4 \mathrm{a}$ & MR & $5,190 \pm 226 a$ & $5,639 \pm 197 a$ & $8.9 \pm 3.4 \mathrm{a}$ & $\mathrm{T}$ \\
\hline Alturas & $6.5 \pm 3.6 \mathrm{a}$ & MS & $5,543 \pm 132 a$ & $6,008 \pm 168 a$ & $8.4 \pm 2.4 \mathrm{a}$ & $\mathrm{T}$ \\
\hline Seahawk & $9.9 \pm 3.0 \mathrm{a}$ & MS & $5,373 \pm 254 a$ & $5,903 \pm 251 \mathrm{a}$ & $10.0 \pm 4.7 \mathrm{a}$ & $\mathrm{T}$ \\
\hline UI Stone & $10.9 \pm 4.2 \mathrm{a}$ & MS & $5,630 \pm 265 a$ & $6,451 \pm 326 a$ & $14.7 \pm 3.2 \mathrm{a}$ & MT \\
\hline WB6430 & $11.9 \pm 2.9 \mathrm{a}$ & MS & $5,949 \pm 195 \mathrm{a}$ & $6,531 \pm 205 a$ & $9.9 \pm 2.8 \mathrm{a}$ & $\mathrm{T}$ \\
\hline Mean & 5.2 & MR & 5,674 & 6,206 & 9.4 & $\mathrm{~T}$ \\
\hline$P>F$ & 0.1467 & $\ldots$ & 0.3972 & 0.5763 & 0.7341 & $\ldots$ \\
\hline $\mathrm{HSD}_{0.05}$ & $\mathrm{~ns}$ & $\ldots$ & $\mathrm{ns}$ & $\mathrm{ns}$ & $\mathrm{ns}$ & $\ldots$ \\
\hline
\end{tabular}

u Means and standard error of the mean for three replicates of white female counts and four replicates of grain yield. Means followed by the same letter within a column did not differ significantly at $\alpha=0.05$ as determined by Tukey's honestly significant difference (HSD) test; ns = not significant.

v Number of $H$. avenae white females produced per plant for the control (no-nematicide) treatment only; sampling was performed at approximately the time of anthesis.

${ }^{\text {w }}$ Phenotypic resistance reaction: very resistant (VR; $\leq 1$ swollen female/plant), resistant (R; 1.1 to 3 ), moderately resistant (MR; 3.1 to 6), moderately susceptible (MS; 6.1 to 12 ), susceptible (S; 12.1 to 25$)$, or very susceptible (VS; $>25$ ).

$\times$ Nematicide treatment included application of aldicarb (at $4.2 \mathrm{~kg} / \mathrm{ha}$ ) in the seed row at the time of planting.

y Percentage increase in grain yield due to application of nematicide.

${ }^{z}$ Phenotypic tolerance reaction: very tolerant (VT; $<5 \%$ yield response to nematicide), tolerant (T; 5 to $10 \%$ ), moderately tolerant (MT; 10 to $15 \%$ ), moderately intolerant (MI; 15 to $30 \%$ ), intolerant (I; 30 to $50 \%$ ), or very intolerant (VI; >50\%). 
wheats but was not significant $(P=0.08)$ for the hard wheat experiment. When all cultivars in the control treatment were examined during 2014, the cultivar effect was significant in both experiments: $P<0.03$ for soft wheats and $P<0.0001$ for hard wheats. The range of low to high $H$. avenae density for the soft wheat cultivars during 2014 was from $455 \mathrm{eggs} / \mathrm{kg}$ of soil for IDO 852 to $9,665 \mathrm{eggs} / \mathrm{kg}$ for UI Stone (Table 5). The range for the hard wheat cultivars was from $411 \mathrm{eggs} / \mathrm{kg}$ for WB-Rockland to $9,313 \mathrm{eggs} / \mathrm{kg}$ for 'Choteau' (Table 5).

Regression analyses indicated the presence of significant associations between numbers of white females developed on roots and eggs extracted from cysts after harvest for both market groups of spring wheat during each year. The strongest models for entries of soft white spring wheat occurred with polynomial regressions of data averaged over three replicates for individual cultivars (Fig. 2). This relationship also occurred for hard wheats during 2013 (Fig. 2) but the strongest model during 2014 occurred with a linear regression of transformed data of all plots $\left(P=0.0005, R^{2}=0.1599, n=72\right)$. For the latter group of hard wheats during 2014, the polynomial regression using means of raw data for each cultivar, as was used for other groups, was weaker than for the transformed data but is presented for uniformity of presentation in Figure 2. Numbers of eggs increased with increasing numbers of white females for soft wheat cultivars each year. This also occurred up to a density of approximately 40 cysts/plant for the group of hard wheats during 2013, whereupon the egg count diminished when the density of white females exceeded 60 per plant. There was no clear association between white females and eggs in the hard wheats during 2014.

\section{Discussion}

Fisher (1982) demonstrated that wheat cultivars were generally more profitable in $H$. avenae-infested fields when the cultivars were resistant and tolerant rather than susceptible and intolerant to this cereal cyst nematode. Of the 39 cultivars examined, we detected dual

Table 4. Summary of cultivar tolerance and resistance traits for data grouped over 2 years

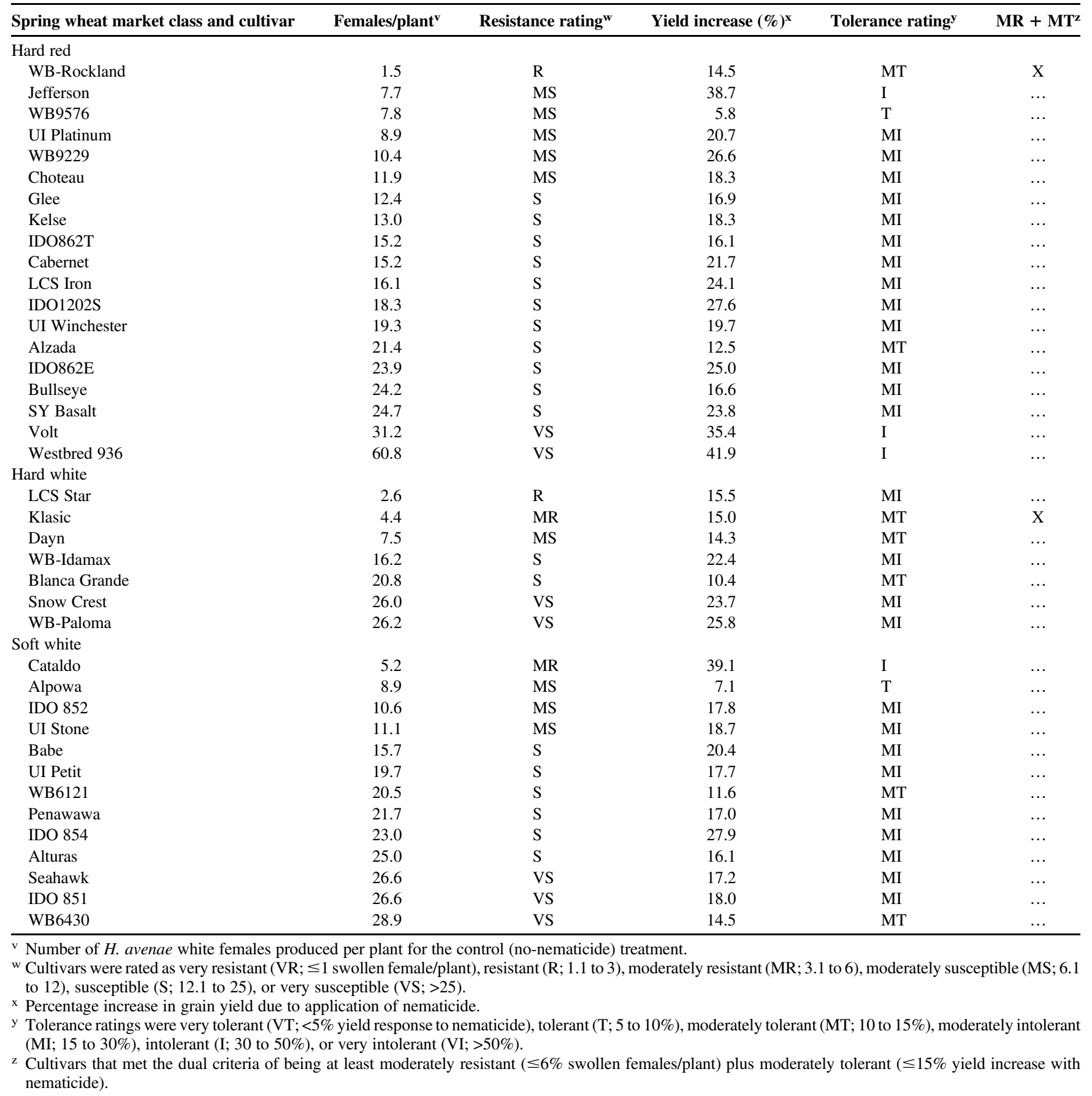


traits of resistance plus tolerance in one cultivar of hard red wheat (WB-Rockland) and one cultivar of hard white wheat (Klasic). One additional cultivar of hard white wheat (LCS Star) also very nearly met our preestablished criteria for this dual-trait ranking and was considered agronomically acceptable for this purpose. We were unsuccessful in identifying these dual traits in soft white spring wheat cultivars.

These experiments contributed to an understanding of relative resistances and tolerances of North American spring wheat cultivars to $H$. avenae. We ranked 9 of 39 wheat entries $(23 \%)$ as tolerant ( 2 entries) or moderately tolerant ( 7 entries) and no entries as very tolerant. In a study with barley at the same location and during the same years (Marshall and Smiley 2016), we ranked 69\% of 45 barley entries as very tolerant (11 entries), tolerant (11 entries), or moderately tolerant (9 entries). These data confirm previous reports that spring wheat yields are more negatively affected than spring barley yields in fields infested by H. avenae in Sweden (Andersson 1982) and Australia (Fisher 1982).

Earlier comparative studies of spring wheat cultivars in field trials or in greenhouse trials with $H$. avenae-infested soils collected from Idaho, Oregon, and Washington have shown that the cultivars were equally resistant or tolerant to the $H$. avenae populations in each state (Smiley et al. 2011a, 2013). Therefore, the resistance and tolerance traits identified for wheat cultivars in these trials in Idaho are anticipated to be applicable to $H$. avenae-infested fields elsewhere in the PNW.

The origins of resistance traits detected in some cultivars examined in our trials are unknown. It appears that none of the accessions are designated as having resistance to $H$. avenae (USDA-ARS-GRIN 2015). We previously reported that WB-Rockland was resistant but intolerant of $H$. avenae in Idaho and Washington and that the source of the resistance trait was unknown (Smiley et al. 2013). In the current experiments, WB-Rockland was determined to be both resistant and moderately tolerant. International exchanges of wheat germplasm are likely to have introgressed resistance genes into cultivars such as WB-Rockland, Klasic, and LCS Star, and those previously undetected traits are being unveiled by tests such as those reported here. Additional studies are required to identify genes responsible for these traits, and to expand their distribution within PNW wheat cultivars expected to be adapted to areas where fields are infested by $H$. avenae.

We determined here and in our simultaneous studies of spring barley (Marshall and Smiley 2016) that wheat cultivars exhibiting resistance to $H$. avenae exhibited an incidence of root knotting similar to that found on susceptible cultivars. Second-stage juveniles penetrate epidermal cells behind the root cap (Price and Hague 1981; Price et al. 1983) and move intracellularly to the growth zone (Baldwin and Mundo-Ocampo 1991). These phases of disease development occur equally in resistant and susceptible cultivars (Andersen 1961; Cui et al. 2012; O'Brien and Fisher 1974, 1977; Ogbonnaya et al. 2001; Oka et al. 1997). The developing females reprogram root cells to induce the formation of specialized feeding cells (Hewezi et al. 2012) but cells of the developing syncytium then deteriorate in resistant cultivars, causing death or suppressed reproductive capacity of the female in resistant cultivars (Andres et al. 2001; Oka et al. 1997; Seah et al. 2000). Numbers of nematodes within roots and numbers of sites of root-knotting continue to increase as susceptible plants become older, and numbers of nematodes decrease but sites of root-knotting remain the same as resistant plants become older (O'Brien and Fisher 1977). Therefore, resistant cultivars reduce the density of $H$. avenae in soil but may still be intolerant and have reduced grain yield if those cultivars exhibit a high level of sensitivity to root injury before the resistance mechanism becomes activated.

In our field studies, the disease incidence (root-knotting symptom) did not differ significantly in resistant and susceptible cultivars sampled at the time of plant anthesis. However, the disease incidence was slightly but significantly less in aldicarb-treated compared with control plots. The application of aldicarb greatly reduced the development of swollen white females on susceptible cultivars and reduced the postharvest density of $H$. avenae eggs by up to $82 \%$. Resistant cultivars also reduced the number of swollen white females and the density of $H$. avenae eggs per kilogram of soil.

An initial density of more than $3,000 \mathrm{H}$. avenae eggs plus juveniles $/ \mathrm{kg}$ of soil is generally capable of reducing yields of wheat, barley, oat, and rye (Andersson 1982). During 2013, the postharvest densities of $H$. avenae in plots of resistant wheat and in the aldicarb treatment were never reduced to a level that would be too low to affect the productivity of a subsequently planted intolerant cultivar of wheat or barley because the dry soil contained a mixture of eggs from recently developed cysts as well as from cysts produced on previous

Table 5. Density of eggs released from Heterodera avenae cysts extracted from soils following the grain harvest of spring wheat cultivars (13 soft white, 19 hard red, and 7 hard white) in two fields near St. Anthony, ID during 2013 and $2014^{\mathrm{x}}$

\begin{tabular}{|c|c|c|}
\hline \multirow[b]{2}{*}{ Cultivars } & \multicolumn{2}{|c|}{ Eggs/kg of soily } \\
\hline & 2013 & 2014 \\
\hline \multicolumn{3}{|l|}{ Soft white } \\
\hline IDO 852 & $\ldots$ & $455 \pm 240 \mathrm{~b}$ \\
\hline Babe & $\ldots$ & $763 \pm 103 a b$ \\
\hline IDO 851 & $133,584 \pm 6,709 \mathrm{a}$ & $1,129 \pm 222 \mathrm{ab}$ \\
\hline Penawawa & $\ldots$ & $2,240 \pm 446 \mathrm{ab}$ \\
\hline Seahawk & $\ldots$ & $2,390 \pm 561 \mathrm{ab}$ \\
\hline Cataldo & $45,672 \pm 10,759 b$ & $2,523 \pm 706 a b$ \\
\hline Alturas & $\ldots$ & $2,537 \pm 726 a b$ \\
\hline Alpowa & $57,904 \pm 14,605 \mathrm{~b}$ & $2,655 \pm 131 \mathrm{ab}$ \\
\hline IDO 854 & $\ldots$ & $3,344 \pm 1,286 \mathrm{ab}$ \\
\hline UI Petit & $\ldots$ & $3,583 \pm 2,599 \mathrm{ab}$ \\
\hline WB6121 & $\ldots$ & $5,485 \pm 3,329 \mathrm{ab}$ \\
\hline WB6430 & $78,669 \pm 20,364 a b$ & $6,703 \pm 3,215 \mathrm{ab}$ \\
\hline UI Stone & $71,192 \pm 11,979 a b$ & $9,665 \pm 4,017 \mathrm{a}$ \\
\hline Mean & 77,604 & 3,327 \\
\hline$P>F$ & 0.0008 & 0.0397 \\
\hline \multicolumn{3}{|c|}{ Hard red and hard white $\mathrm{z}$} \\
\hline WB-Rockland & $10,384 \pm 1,608 \mathrm{c}$ & $411 \pm 52 \mathrm{c}$ \\
\hline LCS Iron & $\ldots$ & $719 \pm 53 \mathrm{bc}$ \\
\hline SY Basalt & $72,218 \pm 13,099 \mathrm{a}$ & $953 \pm 431 b c$ \\
\hline WB9229 & $\ldots$ & $983 \pm 332 b c$ \\
\hline Dayn (W) & $\ldots$ & $1,027 \pm 610 \mathrm{bc}$ \\
\hline Alzada & $\ldots$ & $1,085 \pm 375 b c$ \\
\hline Klasic (W) & $26,532 \pm 4,235 \mathrm{a}-\mathrm{c}$ & $1,276 \pm 621 \mathrm{bc}$ \\
\hline LCS Star (W) & $15,620 \pm 3,588 \mathrm{bc}$ & $1,452 \pm 1,009 \mathrm{bc}$ \\
\hline Blanca Grande (W) & $\ldots$ & $1,804 \pm 466 \mathrm{a}-\mathrm{c}$ \\
\hline Kelse & $\ldots$ & $1,804 \pm 954 \mathrm{a}-\mathrm{c}$ \\
\hline UI Platinum & $\ldots$ & $1,936 \pm 268 \mathrm{a}-\mathrm{c}$ \\
\hline WB9576 & $\ldots$ & $2,424 \pm 159 \mathrm{a}-\mathrm{c}$ \\
\hline Bullseye & $\ldots$ & $2,449 \pm 371 \mathrm{a}-\mathrm{c}$ \\
\hline UI Winchester & $\ldots$ & $2,464 \pm 233 \mathrm{a}-\mathrm{c}$ \\
\hline WB-Idamax (W) & $\ldots$ & $2,919 \pm 852 \mathrm{a}-\mathrm{c}$ \\
\hline Snow Crest (W) & $\ldots$ & $2,992 \pm 753 \mathrm{a}-\mathrm{c}$ \\
\hline Jefferson & $54,736 \pm 20,676 a b$ & $3,095 \pm 2,062 \mathrm{a}-\mathrm{c}$ \\
\hline WB-Paloma (W) & $\ldots$ & $3,828 \pm 1,836 \mathrm{a}-\mathrm{c}$ \\
\hline IDO1202S & $\ldots$ & $4,385 \pm 997 \mathrm{a}-\mathrm{c}$ \\
\hline Westbred 936 & $39,204 \pm 15,376 \mathrm{ab}$ & $5,529 \pm 816 a b$ \\
\hline Volt & $\ldots$ & $6,468 \pm 3,537 \mathrm{ab}$ \\
\hline IDO862E & $\ldots$ & $6,732 \pm 1,962 \mathrm{ab}$ \\
\hline Cabernet & $\ldots$ & $7,260 \pm 3,845 \mathrm{ab}$ \\
\hline IDO862T & $\ldots$ & $7,363 \pm 2,411 \mathrm{ab}$ \\
\hline Glee & $49,779 \pm 2,259 a b$ & $8,169 \pm 3,590 \mathrm{ab}$ \\
\hline Choteau & $\ldots$ & $9,313 \pm 1,188 \mathrm{a}$ \\
\hline Mean & 38,385 & 3,417 \\
\hline$P>F$ & 0.0011 & $<0.0001$ \\
\hline
\end{tabular}

${ }^{x}$ Means and standard error of the mean for three replicates. Means followed by the same letter within a column did not differ significantly at $\alpha=0.05$ as determined by Tukey's honestly significant difference (HSD) test.

${ }^{y}$ Number of $H$. avenae eggs $/ \mathrm{kg}$ of soil for the control (no-nematicide) treatment only; extraction of cysts was performed from soil that was dry following harvest.

${ }^{\mathrm{z}}$ All cultivars are hard red spring except those designated by (W), which are hard white spring wheat cultivars. 
crops of wheat or barley. In all, 40 to $90 \%$ of $H$. avenae eggs hatch from cysts during a single season (Andersen 1961; Andersen and Andersen 1970). Therefore, hatching from individual cysts is spread over many years, causing two-year rotations of cereals with nonhost crops to be inadequate for reducing the residual risk to a subsequent cereal crop. We demonstrated that this would occur even when a susceptible crop would follow a resistant cultivar or a soil that had been treated with a nematicide such as aldicarb. These observations have been consistent in our studies of wheat and barley resistance and tolerance to H. avenae (Marshall and Smiley 2016; Smiley et al. 2011a, 2013).

During 2014, with the exception of two hard red wheat cultivars ('Volt' and 'WB936'), we detected very few white females on roots after heading but a high incidence and severity of the root-knotting symptom on seedlings. We had not encountered this apparent anomaly during seven previous years in which we conducted field trials on H. avenae-infested fields in three PNW states, including 4 years of testing on fields of the Idaho farm where the current research was conducted. We did, however, have a similar experience on three adjacent barley trials at that location during the same year (Marshall and Smiley 2016). The initial density of $H$. avenae eggs plus juveniles on the field where our 2014 trials were established was considered acceptable for assaying wheat $(>3,000 \mathrm{H}$. avenae eggs plus juveniles $/ \mathrm{kg}$ of soil) (Andersson 1982). During 2014, the most susceptible cultivar in the soft wheat and hard wheat trial produced 12 and 51 white females/plant, respectively, with initial $H$. avenae densities of 11,880 and 3,309 eggs plus juveniles/kg of soil for the soft wheat and hard wheat experiments, respectively. It appeared that the initial density during 2014 was sufficient to attain a valid differentiation among cultivars.

Although it remains unclear as to why so few new cysts developed in most cultivars during 2014, we believe the anomaly may have been associated with soil temperature. We planted our trials when the temperature at the depth of planting was $6.7^{\circ} \mathrm{C}$ during 2014. Seedlings emerged 3 weeks after planting. $H$. avenae juveniles in the Bashkir region of central Russia emerged from cysts at temperatures of $5^{\circ} \mathrm{C}$ and above (Tikhonova 1971). During a single season of testing in the PNW, second-stage juveniles began emerging from cysts when average weekly air temperatures stabilized between 2 and $5^{\circ} \mathrm{C}$ (Smiley et al. 2005). We assumed that juveniles began to emerge from cysts at the approximate time we planted our trials during 2014 (Kerry and Jenkinson 1976; Tikhonova et al. 1975). However, Andersen (1961) demonstrated that the specific chronological timing of the primary hatch can vary greatly over seasons.
$\mathrm{Li}$ et al. (2012) reported that $16^{\circ} \mathrm{C}$ was the optimum temperature for penetration of roots by $H$. avenae, and 18 to $22^{\circ} \mathrm{C}$ was the optimum range of temperatures for juveniles to go through molts as they develop into gravid females. In this study, and in accordance with our previous experience (Smiley et al. 2005), we assumed that the density of juveniles in soil continued to increase sharply as the soil warmed during the 3 weeks between planting and seedling emergence. We also assumed that juveniles would be capable of invading roots for at least 3 weeks after they emerged from cysts, as was reported by Davies and Fisher (1976). In our study, during 2014, fewer H. avenae eggs than had been anticipated were detected in soil following the harvests of even the most susceptible wheat cultivars. This also occurred in each of three adjacent spring barley trials (Marshall and Smiley 2016). It is possible that the low numbers of swollen white females occurred because the primary hatching period occurred later than anticipated during 2014, which may have led to too few growing degree days for molting and egg production between the date of root invasion and crop maturation. However, it is also plausible that this observation could have been affected by marginal levels of initial inoculum, a temperature suboptimal for development of gravid females, a difference of soil sampling methods during 2013 and 2014, or an undetected anomaly associated with the procedures used for extraction of cysts and counting of eggs released from cysts. A discussion of these potential explanations was provided by Marshall and Smiley (2016). In short, none of these potential reasons appears to plausibly explain the phenomenon we experienced during 2014.

Comparisons of numbers of white females developed on each cultivar and the number of eggs extracted from cysts after harvest showed that the two methods for assessing resistance to $H$. avenae were significantly correlated for soft white and hard red spring wheat cultivars during 2013 but only for soft white cultivars during 2014. The peak density of eggs recovered from the soils used to produce hard wheat cultivars occurred when approximately 40 white females had been produced on each plant. When the count of white females was elevated above 60 per plant, there was an apparent decrease in numbers of eggs per cyst, indicating the possibility of competition among white females for limited plant nutrients when the number of females exceeds a certain density. This relationship has been described previously (Andersen 1961). The lack of association between white females and eggs for the hard wheats during 2014 indicates the probability of an error either in counting white females or in recovering cysts from soil. A loss of white females could have occurred either when digging or washing roots. Alternatively, if the
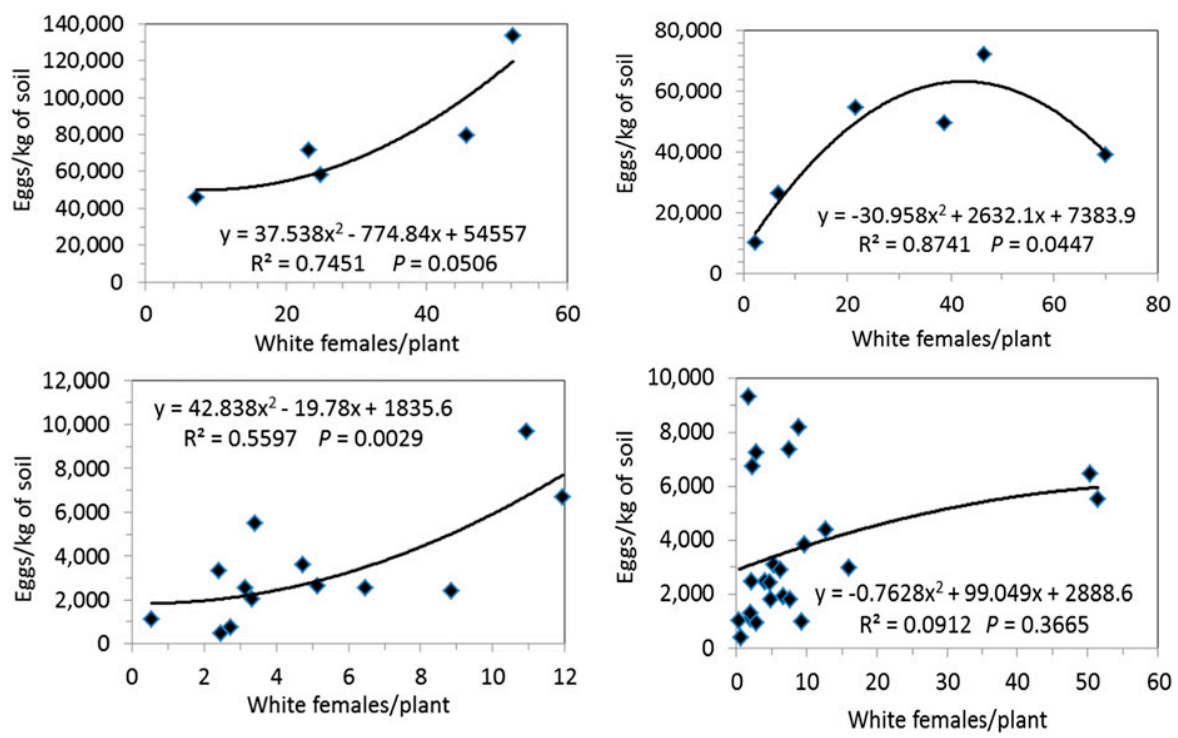

Fig. 2. Associations between number of white females produced on individual cultivars of spring wheat and the density of eggs extracted from cysts in the soils upon which those cultivars were produced during 2013: soft white spring wheat (left column) and hard red plus hard white spring wheat (right column) during 2013 (top row) and 2014 (bottom row). 
sampling occurred when white females were transitioning into brown cysts in the hard wheats, an error could have occurred in distinguishing some of the newly formed cysts from those remaining in soil after previous wheat crops.

In conclusion, we found that three spring wheat cultivars (Klasic, WB-Rockland, and LCS Star) expressed acceptable levels of both tolerance and resistance to $H$. avenae in the United States. We also identified additional cultivars that were either resistant or tolerant to $H$. avenae. We conclude that the spring wheat cultivars identified in these experiments can be used to improve production efficiency on fields that are heavily infested by $H$. avenae. This finding indicates that it should be possible to identify even more cultivars with the resistance plus tolerance traits during evaluations of greater numbers and a greater diversity of wheat genotypes. Finally, we found that the two methods used to evaluate resistance in these experiments were mostly well correlated although, for an unknown reason, that was not true for the hard wheats during 2014.

\section{Acknowledgments}

We thank D. Daw (St. Anthony, ID) for land and crop management assistance; C. Jackson, T. Shelman, S. Arcibal, L. Beck, M. Carrillo, and E. Serna (University of Idaho, Aberdeen) and J. Gourlie, K. Rhinhart, P. Thorgersen, A. Hitzman, and N. Webster (Oregon State University, Pendleton) for technical assistance; and the Idaho Wheat Commission, Oregon Wheat Commission, Washington Wheat Commission, Idaho Agricultural Experiment Station, Oregon Agricultural Experiment Station, and United States Department of Agriculture-Agricultural Research Service Root Disease and Biological Control Unit (at Pullman, WA) for funding. Discounted nematode testing fees were provided by Western Laboratories (Parma, ID).

\section{Literature Cited}

Andersen, K., and Andersen, S. 1970. [Decrease of cereal cyst nematode infestation after growing resistant barley cultivars of grasses.] Tidsskr. Planteavl 74:559565 .

Andersen, S. 1961. Resistens mod Havreål Heterodera avenae. Meddelelse Konelige Vet. Landbrug. Plantekult. 68 Danish Scientific Publishers, Copenhagen Denmark.

Andersson, S. 1982. Population dynamics and control of Heterodera avenae-A review with some original results. EPPO Bull. 12:463-475.

Andres, M. F., Melillo, M. T., Delibes, A., Romero, M. D., and Bleve-Zacheo, T. 2001. Changes in wheat root enzymes correlated with resistance to cereal cyst nematodes. New Phytol. 152:343-354.

Baldwin, J. G., and Mundo-Ocampo, M. 1991. Heteroderinae, cyst- and non-cystforming nematodes. Pages 275-362 in: Manual of Agricultural Nematology. W. R. Nickle, ed. M. Dekker, New York.

Brown, R. H. 1987. Control strategies in low-value crops. Pages 351-387 in: Principles and Practice of Nematode Control in Crops. R. H. Brown and B. R. Kerry, eds. Academic Press, Sydney, Australia.

Cook, R., and Evans, K. 1987. Resistance and tolerance. Pages 179-231 in: Principles and Practice of Nematode Control in Crops. Brown, R. H., and Kerry, B. R., eds. Academic Press, Sydney.

Cui, L., Gao, X., Wang, X. M., Jian, H., Tang, W. H., Li, H. L., and Li, H. J. 2012. Characteristics of interaction between wheat roots with different resistance and Heterodera filipjevi. Acta Agron. Sin. 38:1009-1017.

Davies, K. A., and Fisher, J. M. 1976. Duration of infectivity of second stage larvae of Heterodera avenae. Nematologica 22:163-168.

Fisher, J. M. 1982. Problems with the use of resistance in wheat to the Australian pathotypes of Heterodera avenae. EPPO Bull. 12:417-421.

Hewezi, T., Maier, T. R., Nettleton, D., and Baum, T. J. 2012. The Arabidopsis microRNA396-GRF1/GRF3 regulatory module acts as a developmental regulator in the reprogramming of root cells during cyst nematode infection. Plant Physiol. 159:321-335.

Kerry, B. R., and Jenkinson, S. C. 1976. Observations on emergence, survival and root invasion of second-stage larvae of the cereal cyst nematode, Heterodera avenae. Nematologica 22:467-474.
Li, X. H., Ma, J., and Chen, S. L. 2012. Effect of temperature on the penetration and development of Heterodera avenae. J. Triticeae Crops 32:977-981.

Marshall, J. M., Jackson, C. A., Shelman, T., Beck, L., and O'Brien, K. 2015. 2014 Small Grains Report, South Central and Southeast Idaho Cereals Research and Extension Program. Idaho Agric. Exp. Stn. Univ. Idaho Res. Bull. 186.

Marshall, J. M., and Smiley, R. W. 2016. Spring barley resistance and tolerance to the cereal cyst nematode Heterodera avenae. Plant Dis. 100:396-407.

O'Brien, P. C., and Fisher, J. M. 1974. Resistance within wheat, barley and oat cultivars to Heterodera avenae in South Australia. Aust. J. Exp. Agric. Anim. Husb. 14:399-404.

O'Brien, P. C., and Fisher, J. M. 1977. Development of Heterodera avenae on resistant wheat and barley cultivars. Nematologica 23:390-397.

Ogbonnaya, F. C., Subrahmanyam, N. C., Moullet, O., de Majnik, J., Eagles, H. A. Brown, J. S., Eastwood, R. F., Kollmorgan, J., Appels, R., and Lagudah, E. S. 2001. Diagnostic DNA markers for cereal cyst nematode resistance in bread wheat. Aust. J. Agric. Res. 52:1367-1374.

Oka, Y., Chet, I., and Speigel, Y. 1997. Accumulation of lectins in cereal roots invaded by the cereal cyst nematode Heterodera avenae. Physiol. Mol. Plant Pathol. 51:333-345.

Price, N. S., Clarkson, D. T., and Hague, N. G. M. 1983. Effect of the invasion by cereal cyst nematode (Heterodera avenae) on the growth and development of the seminal roots of oats and barley. Plant Pathol. 32:377-383.

Price, N. S., and Hague, N. G. M. 1981. The invasion of root tips of cereals by the cereal cyst nematode Heterodera avenae. Ann. Appl. Biol. 99:301-306.

Rivoal, R., and Cook, R. 1993. Nematode pests of cereals. Pages 259-303 in: Plant Parasitic Nematodes in Temperate Agriculture. K. Evans, D. L. Trudgill, and J. M. Webster, eds. CAB International, Wallingford, UK.

Seah, S., Miller, C., Sivasithamparam, K., and Lagudah, E. S. 2000. Root responses to cereal cyst nematode (Heterodera avenae) in hosts with different resistance genes. New Phytol. 146:527-533.

Smiley, R. W. 2009. Occurrence, distribution and control of Heterodera avenae and $H$. filipjevi in the western USA. Pages 35-40 in: Cereal Cyst Nematodes: Status, Research and Outlook. I. T. Riley, J. M. Nicol, and A. A. Dababat, eds. CIMMYT, Ankara, Turkey.

Smiley, R. W., Gourlie, J. A., Rhinhart, K. E. L., Marshall, J. M., Anderson, M. D., and Yan, G. P. 2012. Influence of nematicides and fungicides on spring wheat in fields infested with soilborne pathogens. Plant Dis. 96:1537-1547.

Smiley, R. W., Ingham, R. E., Uddin, W., and Cook, G. H. 1994. Crop sequences for managing cereal cyst nematode and fungal populations of winter wheat. Plant Dis. 78:1142-1149.

Smiley, R. W., Marshall, J. M., Gourlie, J. A., Paulitz, T. C., Kandel, S. L., Pumphrey, M. O., Garland-Campbell, K., Yan, G. P., Anderson, M. D., Flowers, M. D., and Jackson, C. A. 2013. Spring wheat tolerance and resistance to Heterodera avenae in the Pacific Northwest. Plant Dis. 97: 590-600.

Smiley, R. W., Marshall, J. M., and Yan, G. P. 2011a. Effect of foliarly-applied spirotetramat on reproduction of Heterodera avenae on wheat roots. Plant Dis. 95:983-989.

Smiley, R. W., and Nicol, J. M. 2009. Nematodes which challenge global wheat production. Pages 171-187 in: Wheat Science and Trade. B. F. Carver, ed. Wiley-Blackwell, Ames, IA.

Smiley, R. W., Whittaker, R. G., Gourlie, J. A., Easley, S. A., and Ingham, R. E. 2005. Plant-parasitic nematodes associated with reduced wheat yield in Oregon: Heterodera avenae. J. Nematol. 37:297-307.

Smiley, R. W., Yan, G. P., and Pinkerton, J. N. 2011b. Resistance of wheat, barley and oat to Heterodera avenae in the Pacific Northwest USA. Nematology 13 539-552.

Tikhonova, L. V. 1971. Ontogenesis of Heterodera avenae in cereal crops. Byull. Vses. Inst. Gel. Skry. 6:105-114.

Tikhonova, L. V., Ten'kovtseva, E. S., and Airapetyan, V. A. 1975. Data on the organisation of crop rotation schemes aimed at a drastic reduction in the numbers of Heterodera avenae. Byull. Vses. Inst. Gel. Skry. 15: 102-108.

USDA-ARS-GRIN. 2015. National Plant Germplasm System. Online publication United States Department of Agriculture-Agricultural Research Service, Germplasm Resources Information Network. http://www.ars-grin.gov/npgs/

Wilson, R. E., Hollamby, G. J., and Bayraktar, A. 1983. Selecting for high yield potential in wheat with tolerance to cereal cyst nematode. Aust. Field Crops Newsl. 18:21-25 